\title{
Komplikasyon Gelişmiş ve Gelişmemiş Tip II Diabetes Mellitus Hastalarında Paraoksonaz, Arilesteraz, Lipoprotein(a) ve Diğer Lipit Parametreleri Arasındaki İlişki
}

The Relationship Between Paraoxonase, Arylesterase, Lipoprotein(a) and Other Lipid Parameters in Patients with Complicated and Undeveloped Type II Diabetes Mellitus

${ }^{1}$ Uz. Dr. Sakarya Üniversitesi Eğitim ve Araştırma Hastanesi, Biyokimya Laboratuvarı, Sakarya,Türkiye

Prof. Dr. Fırat Üniversitesi, Tip Fakültesi, Tıbbi Biyokimya AD. Elazığ, Türkiye

Sorumlu Yazar: Mehmet Özdin, Uz. Dr. Sakarya Üniversitesi Eğitim ve Araştirma Hastanesi, Biyokimya Laboratuvarı, Sakarya, Türkiye E-mail: drmozdin33@gmail.com Telefon:0 (264) 8884000 .

Başvuru Tarihi: 02.03.2021 Kabul Tarihi: 24.05 .2021 Yayınlanma Tarihi: 25.06.2021

Athf İçin: Mehmet Özdin, M. Ferit Gürsu, Mellitus Hastalarında Paraoksonaz, Arilesteraz, Lipoprotein(a) Ve Diğer Lipit Parametreleri Arasındaki İlişki, 2021;5(2):79-83

Not: Bu yayın 137953 numaralı "koroner Kalp Hastaları Ve Çeşitli Risk Faktörlerini Taşıyan Bireylerde Paraoksonaz1 Aktiviteleri Ve Fenotiplerinin Araştırılması" adlı tezden hazırlanmıştır. Bu tez çalışması Fırat Üniversitesi Araştırma Fonu (FÜNAF-514) tarafindan desteklenmiştir.
(iD) Mehmet Özdin'1, (iD M. Ferit Gürsu²

\section{ÖZ}

Amaç: Tip II diabetes mellitus (tip II DM) günümüzde çok sık görülmekte olup önemli mortalite nedenleri arasındadır. Bu çalışmadaki amacımız komplikasyon gelişmiş ve gelişmemiş tip II DM hastalarında paraoksonaz1 (PON1), arilesteraz (ARE), lipoprotein(a) $[\mathrm{Lp}(\mathrm{a})]$ ve diğer lipit parametreleri arasındaki ilişkiyi belirlemektir. Gereç ve Yöntemler: Fırat Üniversitesi Hastanesi Endokrinoloji kliniğine başvuran 20 komplikasyon gelişmeyen, ve 20 komplikasyon gelişmiş olmak üzere 40 tip II DM hastasının serum PONI, ARE, Lp(a), apo A, apo B ve diğer lipid parametreleri araştırıldı. Kontrol grubu kardiyovasküler hastalığı, diyabeti veya serum lipid düzeyini etkileyen bir hastalığı olmayan sağlıklı 40 bireyden oluşmaktadır. Bulgular: Tip II DM komplikasyon gelişmiş olan hastalarda serum PONI, ARE, total kolesterol, trigliserid, HDL-K, LDL-K, VLDL-K, Lp(a), apo A ve apo B düzeyleri sağlıklı kontrol grubuna göre anlamlı farklılık bulundu $(p<0.05)$. Tip II DM komplikasyon gelişmeyen hastalarında serum HDL-K, LDL-K, Lp(a) ve Apo A düzeyleri sağlıklı kontrol göre anlamlı olarak farklı idi $(p<0.05)$. Ancak serum PONI ve ARE aktiviteleri, total kolesterol, trigliserid, VLDL-K ve apo B düzeyleri sağlıklı kontrol göre anlamlı farklılık gösterdiği saptanmadı ( $>>0.05)$. Sonuç: Tip II DM hastalarında PONI, ARE, total kolesterol, trigliserid, HDL-K, LDL-K, VLDL-K, Lp(a), apo A ve apo $B$ bu parametrelerin kontrolünün yapılması komplikasyonların önlenmesini ve hastalığın seyrini olumlu yönde etkileyecektir.

Anahtar Kelimeler: tip II diabetes mellitus; paraoksonaz; arilesteraz; lipoprotein(a)

\section{ABSTRACT}

Aim: Type II diabetes mellitus (type II DM) is very common today and is among the important causes of mortality. Our aim in this study is to determine the relationship between paraoxonase1 (PON1), arylesterase (ARE), lipoprotein (a) [Lp (a)] and other lipid parameters in patients with complicated and undeveloped type II DM.

Material and Method: Serum PONI, ARE, Lp (a), apo A, apo B and other lipid parameters of 40 type II DM patients, 20 of whom did not develop complications, and 20 developed complications, who applied to Fırat University Hospital Endocrinology clinic were investigated. The control group consists of $\mathbf{4 0}$ healthy individuals without cardiovascular disease, diabetes or a disease affecting serum lipid level.

Result: Serum PONI, ARE, total cholesterol, triglyceride, HDL-K, LDL-K, VLDL-K, Lp (a), apo A and apo $B$ levels were significantly different in patients with type II DM complications compared to the healthy control group ( $p<0.05)$. Serum HDL-K, LDL-K, Lp (a) and Apo A levels were significantly different in patients without type II DM complications $(p<0.05)$. However, serum PONI and ARE activities, total cholesterol, triglyceride, VLDL-K and apo B levels did not differ significantly from healthy control ( $p>0.05)$.

Conclusion: PONI, ARE, total cholesterol, triglyceride, HDL-K, LDL-K, VLDL-K, Lp (a), apo A and apo $B$ control of these parameters will affect the prevention of complications and the course of the disease positively.

Keywords: type II diabetes mellitus; paraoxonase; arylesterase; lipoprotein(a) 
Erişkin bireylerde görülen tip II DM insülin sentezinin bozulması veya insülinin etkisine karşı direnç gelişmesi ile karakterize kronik metabolik bir hastalıktır (1). Tip II DM kan glukoz seviyelerinin yüksekliğiyle seyreden başta karbonhidrat olmak üzere yağ ve protein metabolizmasındaki değişikliklerle kendini göstermektedir (2). Diyabetli kişilerin sayısının gün geçtikçe hızla arttğı bilinmekte olup, yapılan tahminlere göre 2025 yılından önce diyabet hastası sayısı 380 milyonun üstüne çıkacaktır (3). Tip II DM'nin komplikasyonları akut ve kronik olarak ikiye ayrılmaktadır. Tip II DM'de görülen akut komplikasyonlar arasında en sık olarak hipoglisemi, laktik asidoz, ketoasidoz, nonketotik hiperosmolar koma görülebilmektedir (4). Akut olarak ortaya çıkan tip II DM hastalarında yaşamı tehdit edebilmekte ölüme neden olabilmektedir. Tip II DM'de mikrovasküler ve makrovasküler olmak üzere iki kronik komplikasyon görülmektedir. Kronik komplikasyonlar diyabet süresine ve hastalı̆ıın seyri esnasındaki kan glukozu ve HbA1c değerlerine bağlı olarak değişmektedir. Kapiller bazal membran kalınlaşması ve geçirgenlik artı̧ı, trombosit fonksiyonlarında bozulma ve kan viskozitesinde artş mikrovasküler komplikasyonlara neden olmaktadır. Böbrek kapillerlerindeki bozukluğa bağlı olarak ortaya çıkan mikroalbuminüri şeklinde görülen kapiller sızıntısı, trombosit fonksiyonlarındaki bozulmaya bağlı olarak intrvasküler mikrotrombüs oluşumu ve dokularda iskemik hasar gelişebilir. Tip II DM hastalarının yaklaşık 1/3 ile yarısında organ veya doku hasarı gelişmektedir (4-6). Tip II DM'de görülen kronik komplikasyonların en önemlileri koroner arter hastalığı, serebrovasküler hastalıklar ve periferik vasküler hastalıklardır $(7,8)$. Gelişmiş ülkelerde erişkin ölümleri arasında en fazla kardiyovasküler hastalıklara bağlı nedenler bulunmakla birlikte, yapılan çalışmalarda kolesterol düzeylerinin önemli bir rol oynadığı da tespit edilmiştir (9). Tip II DM hastalarında da kolesterol düzeylerinde önemli değişiklikler olmaktadır. Bu nedenle çalışmamızdaki amaç komplikasyon gelişmiş ve gelişmemiş tip II DM hastalarında PON1, ARE, Lp(a) ve total kolesterol, trigliserid, HDL-K, LDL-K, VLDL-K düzeyleri arasındaki ilişkiyi belirlemektir.

\section{GEREÇ VE YÖNTEMLER}

Çalışma grubu, Fırat Üniversitesi Tıp Fakültesi Hastanesi Endokrinoloji kliniğine başvuran 20 komplikasyon gelişmiş ve 20 komplikasyonsuz olmak üzere 40 tip II DM hastası ile kontrol grubu sağ Iıklı 40 kişiden oluşmaktadır. Hasta ve kontrol grubunda serum PONlaktiviteleri, AREaktiviteleri, Lp(a), apoA, apo Bvediğerlipid parametreleriaraştırıldı. Kontrolgrubunuoluşturankişiler de herhangi bir diyet yapmayan, genel olarak bir hastalığa ait ilaç kullanmayan, herhangi bir cerrahi operasyon geçirmemiş, DM, hipertansiyon, kardiyovasküler, renal, hepatikbirrahatsızlıkveyakronikbirrahatsızlığıolmayan, sigaraiçmeyen, sonbirayiçerisinde herhangi bir şikayeti olmayan, aile hikayesinde önemli bir patoloji bulunmayan tamamen sağlıklı kişilerden oluşturulmuştur.

PON1 ve ARE aktiviteleri spektrofotometrik olarak ölçümleri yapılarak hesaplandı. Total kolesterol, trigliserid, HDL-K, LDL-K, VLDL-K ölçümleri Randox kitleri (Randox Laboratories, San Francisco, CA, USA) kullanılarak, OLYMPUS AU 600 marka otoanalizörde (Olympus Optical Co. Ltd, Tokyo, Japan) çalışıldı. Bu parametrelerin sonuçları $\mathrm{mg} / \mathrm{dl}$ olarak verilmiştir. $\mathrm{Lp}(\mathrm{a})$, apo $\mathrm{A}$, apo•B düzeyleri ise protein SPACE cihazında (Schiparelli Biosystem Inc. Netherland) çalışıldı. Sonuçlar ise $\mathrm{Lp}(\mathrm{a})$ için $\mathrm{mg} / \mathrm{dl}$, apo A ve apo $B$ için ise $\mathrm{g} / \mathrm{L}$ olarak verildi.

Çalışmalardan elde edilen verilerin istatistiksel analizi Minitab 10.0 programı kullanılarak yapılmıştır. Komplikasyon gelişmiş ve gelişmemiş olan grupları kontrol grubu ile karşılaştırmalarda student t testi kullanılmıştır. Veriler ortalama \pm standart sapma olarak ifade edildi. Sonuçların tümünde $p<0.05$ değerleri anlamlı olarak kabul edilmiştir.

Etik Komite Onayı: Bu çalışma, Helsinki protokolü komitesinin gereklerine uygun olarak yapıldı ve Fırat Üniversitesi, Tıp Fakültesi, Etik Komitesi tarafindan onaylandı (Karar no: 137953 yıl: 13/01/2003).

\section{BULGULAR}

Çalışmamız kapsamında incelenen parametrelere ait veriler komplikasyon gelişmiş tip II DM grubu (11 kadın, 9 erkek), komplikasyon gelişmemiş tip II DM grubu (11 kadın, 9 erkek), kontrol grubu (23 kadın, 17 erkek) şeklinde ayrılarak Tablo I 'de sunulmuştur.

Komplikasyon gelişmiş tip II DM hastalarının PONI aktiviteleri ve ARE aktiviteleri kontrol grubuna göre istatistiksel olarak anlamlı fark tespit edildi $(p<0.05)$.

Komplikasyon gelişmemiş tip II DM hastalarında ise PONI seviyeleri ve ARE aktiviteleri kontrol grubuna göre istatistiksel olarak anlamlı fark saptanmadı ( $p>0.05)$.

Total kolesterol, trigliserit, VLDL-K, Apo B düzeyleri, komplikasyon gelişmiş tip II DM hastalarında kontrol grubuna göre istatistiksel olarak anlamlı fark tespit edildi $(p<0.05)$. Komplikasyon gelişmemiş tip II DM hastaları ile kontrol grubu arasında ise anlamlı fark saptanmadı $(p>0.05)$.

HDL-K, Apo A düzeyleri, hem komplikasyon gelişmemiş hem de komplikasyon gelişmiş tip II DM hastalarında kontrol grubuna göre istatistiksel olarak anlamlı fark tespit edildi $(p<0.05)$.

LDL-K, Lp(a) düzeyleri, hem komplikasyon gelişmemiş hem de komplikasyon gelişmiş tip II DM hastalarında kontrol grubuna göre istatistiksel olarak anlamlı fark saptandı $(p<0.05)$. 
Tablo1. Komplikasyon gelişmiş ve komplikasyon gelişmemiş tip II DM hasta gruplarındaki PONI ve ARE aktiviteleri, total kolesterol, triglisend, HDL-K, LDL-K, VLDL-K, Lp(a), Apo A ve Apo B düzeylerinin kontrol grubuna göre istatistiksel karşılaştırılması $(a=p<0.05, b=p>0.05)$.

\begin{tabular}{|c|c|c|c|}
\hline Parametreler & $\begin{array}{c}\text { Kontrol } \\
n=40 \\
\text { (Ort } \pm \text { SD) }\end{array}$ & $\begin{array}{l}\text { Komplikasyon } \\
\text { Gelişmiş } \\
\text { Tip II DM n=20 } \\
\text { (Ort } \pm \text { SD) }\end{array}$ & $\begin{array}{c}\text { Komplikasyon } \\
\text { Gelişmemiş } \\
\text { Tip II DM n=20 } \\
\text { (OrttSD) }\end{array}$ \\
\hline Yaş & $53.9 \pm 72$ & $57.6 \pm 5.4 \mathrm{~b}$ & $54.9 \pm 6.9 \mathrm{~b}$ \\
\hline PON1 aktivite (U/L) & $253.82 \pm 51.14$ & $181.10 \pm 32.26 \mathrm{a}$ & $238.45 \pm 31.92 \mathrm{~b}$ \\
\hline ARE aktivite (U/ml) & $167.77 \pm 38.23$ & $120.30 \pm 33.06 \mathrm{a}$ & $140.60 \pm 37.71 \mathrm{~b}$ \\
\hline T. kolesterol (mg/dI) & $178.20 \pm 32.60$ & $214.75 \pm 32.99 \mathrm{a}$ & $199.60 \pm 32.86 \mathrm{~b}$ \\
\hline Trigliserid(mg/dl) & $113.32 \pm 34.31$ & $155.50 \pm 34.25 \mathrm{a}$ & $126.65 \pm 28.74 \mathrm{~b}$ \\
\hline HDL-K (mg/dl) & $51.90 \pm 9.11$ & $35.15 \pm 6.6 \mathrm{la}$ & $39.60 \pm 6.57 \mathrm{a}$ \\
\hline LDL-K (mg/dl) & $85.98 \pm 21.08$ & $123.30 \pm 29.20 \mathrm{a}$ & $120.85 \pm 35.20 \mathrm{a}$ \\
\hline VLDL-K (mg/dl) & $21.80 \pm 8.23$ & $34.60 \pm 9.80 \mathrm{a}$ & $25.70 \pm 6.65 \mathrm{~b}$ \\
\hline $\left.\mathrm{Lp}_{\mathrm{p}} \mathrm{a}\right)(\mathrm{mg} / \mathrm{dl})$ & $8.60 \pm 4.30$ & $34.45 \pm 5.78$ & $21.40 \pm 4.24 a$ \\
\hline ApoA (g/L) & $1.49 \pm 0.30$ & $1.18 \pm 0.24 a$ & $1.18 \pm 0.24 a$ \\
\hline ApoB (g/L) & $1.00 \pm 0.18$ & $1.25 \pm 0.21 \mathrm{a}$ & $1.15 \pm 0.17 \mathrm{~b}$ \\
\hline T. protein (gr/dl) & $7.80 \pm 0.90$ & $7.20 \pm 0.60$ & $7.50 \pm 0.80$ \\
\hline
\end{tabular}

a: kontrol grubuna göre istatistiksel olarak anlamlı fark olan parametreler

b: kontrol grubuna göre istatistiksel olarak anlamlı fark olmayan parametreler

Ort: ortalama SD: standart sapma

\section{TARTIŞMA}

PON1 kısmen HDL-K'nin, LDL-K oksidasyonuna karşı koruyucu etkisinden sorumlu olan lipid peroksitleri hidrolize edebilen HDL-K'ye bağlı bir enzimdir (10). PONI'in lipid metabolizmasında görevli bir enzim olduğu düşüncesiyle DM ile PONI aktivitesi arasında bir ilişki olabileceği araştırılmıştır. Streptozotosin ile diyabet oluşturulan ratlarda PONI aktivitesi 6 aylık periyotta ölçülmüştür. 6 ay sonunda PONI aktivitesi kontrol grubunun \% 36'sı kadar azaldığı tespit edilmiştir (11). Tip II DM hastalarında yapılan bir çalışmada PON1 seviyelerinin kontrol grubuna göre daha düşük, Lp(a) seviyelerinin ise daha yüksek olduğu bulunmuştur (12). Tip II DM hastalarında yapılan diğer bir çalışmada PON1 aktivitesinin kontrol grubuna göre anlamlı düşük olduğu tespit edilmiştir (13). Dislipidemi, DM ve ileri yaş gibi oksidatif stresin arttğı olaylarda PON1 düzeyi düşük bulunmuştur (14). Yaptığımız çalışmada tip II DM komplikasyon gelişmiş olan hastaların ve gelişmemiş olan grupta PON1 değerlerinin kontrol grubuna göre düşük bulduk ve komplikasyon gelişmiş olan tip II DM hastalarında istatiksel olarak anlamlı olduğunu tespit ettik.

ARE, esterazgrubundan birenzimdir. Diyabethastalarındayapılan çalışmadaserum/plazma AREvePON1aktivitelerininazaldığı tespitedilmiştir(15). YapttğımızçalışmadatipIIDMkomplikasyongelişmişolanvegelişmemişolangruptaPON1değerlerininkontrol grubuna göre düşük bulduk ve komplikasyon gelişmiş olan tip II DM hastalarında istatiksel olarak anlamlı olduğunu tespit ettik.

Lp(a) ilk kez 1963 yılında Berg tarafindan tanımlanmıştı. Lp(a) ile ilgili son zamanlarda birçok çalışma yapılmış ve bu aterojen lipoproteinin, diyabetli hastalarda yüksek düzeylerde görüldüğü saptanmıştır (10). DM hastalarında yapılan bir çalışmada Lp(a) seviyelerinin daha yüksek olduğu bulunmuştur (12). 134 tip II DM hastası ve 100 kontrol olgusuyla yapılan çalışmada plazma Lp(a) düzeylerinin, tip II DM hastalarında anlamlı bir şekilde yüksek olduğu gösterilmiştir (16). Yaptığımız çalışmada tip II DM hastalarının komplikasyon gelişmiş olan ve gelişmemiş olan grupta Lp(a) değerlerinin kontrol grubuna göre yüksek bulduk ve her iki grup kontrol grubu ile karşılaştrıldığında istatiksel olarak anlamlı olduğunu tespit ettik.

DM hastalarında en sık görülen lipid bozuklukları plazma kolesterol yüksekliği ile birlikte trigliserid yüksekliğinin eşlik etmesi veya yalnız kolesterol yüksekliğidir. Toplam 709 tip II DM hastasında yapılan çalışmalarda 355'inde (\%50.1) serum total kolesterol düzeyi kontrol grubuna göre yüksek saptanmıştı ( $>200 \mathrm{mg} / \mathrm{dl}, \mathrm{p}<0.001)$ (16). Tip II 
DM hastalarında yapılan bir çalışmada trigliserid ve VLDL-K değerleri kontrol grubuna göre istatiksel olarak yüksek, HDL-K değerleri ise düşük bulunmuştur (13). Yaptı̆ı̆ız çalışmada tip II DM hastalarının komplikasyon gelişmiş olan ve gelişmemiş olan grupta total kolesterol değerlerinin kontrol grubuna göre yüksek bulduk ve komplikasyonlu grupta istatiksel olarak anlamlı olduğunu tespit ettik. Yapılan bir çalışmada tip II DM hastalarının \%59,1'nde kontrol grubuna göre trigliserid düzeyi yüksek olarak tespit edilmiş ve istatiksel olarak anlamlı bulunmuştur (13). Yaptiğımız çalışmada tip II DM hastalarının komplikasyon gelişmiş olan ve gelişmemiş olan grupta trigliserid değerlerinin kontrol grubuna göre yüksek bulduk ve komplikasyon gelişmiş olan grupta istatiksel olarak anlamlı olduğunu tespit ettik.

LDL-K partikülleri özellikle ateroskleroz ve serebrovaskuler hastalıklarda bağlantılı olan temel lipoproteinlerdir. En aterojenik formu Okside LDL-K'dir (17). 135 erkek, 209 kadın toplam 344 diyabetik olan hastalarda yapılan bir çalışmada ortalama LDL-K düzeyleri $126.4 \pm 33.5 \mathrm{mg} / \mathrm{dl}$ olarak saptanmıştır (9). Yaptığımız çalışmada LDL-K düzeylerini $123.30 \pm 29.20$ olarak bulduk ve komplikasyongelişmişolanvegelişmemiştip IIDMhastalarındakontrolgrubunagöreistatikselolarakanlamlıolduğunutespitettik.

HDL-K, LDL-K oksidayonunu inhibe ederek ateroskleroz gelişimini engeller. Aynı zamanda HDL-K makrofajların arterial lümene yapışmalarını önlerler. HDL-K'deki artş̧ar ateroskleroz ve kardiyovasküler hastalıkların gelişmesini önleyici etkisi bulunmaktadır (16). Yaptığımız çalışmada HDL-K ve Apo A düzeylerini komplikasyon gelişmiş olan ve gelişmemiş tip II DM hastalarında kontrol grubuna göre istatiksel olarak anlamlı olduğunu tespit ettik. Apo B düzeylerini komplikasyon gelişmiş olan tip II DM hastalarında kontrol grubuna göre istatiksel olarak anlamlı olduğunu saptadık.

\section{SONUÇ}

Son yıllarda yapılan çalışmalar PONI, ARE, Lp(a) ve diğer lipid parametrelerinin tip II DM hastalığında önemli birer parametre olduklarını ortaya koymuştur. Tüm bu parametrelerin özellikle komplikasyon gelişmiş olan tip II DM hastalarında kontrol grubuna göre anlamlı olması bu hastalığın takibinde bu parametrelerin önemini bir kat daha artirmaktadır.

\section{BILDIRIMLER}

Çıkar Çatışması: Yazarlar arasında çıkar çatışması yoktur.

Finansal Destek: Herhangi bir kurumdan maddi destek alınmamıştır.

Etik Kurul İzni: Bu çalışma, Helsinki protokolü komitesinin gereklerine uygun olarak yapıldı

ve Fırat Üniversitesi, Tıp Fakültesi, Etik Komitesi tarafindan onaylandı (Karar no: 137953 yıl: 13/01/2003). 


\section{KAYNAKLAR}

1.Kandemir YB, Güntekin Ü, Aydın Ç, Görgişen G. Diyabetik Kardiyomiyopati ve G Proteini. Van Tıp Derg. 2019;26(3):402-407. DOI:10.5505/vtd.2019.88156

2.Ekim M, Ekim H. Tip 2 Diabetiklerde Faktör V Leiden Mutasyonu Sıklı̆̆ı. Van Tıp Derg 2020;27(2):166-170. DOI:10.5505/ vtd.2020. 604204.

3.Keskin Ö, Balcı B. Diabetes Mellitus ve Kardiyovasküler Komplikasyonlar. Kafkas J Med Sci 2011;1(2):81-85 DOI:10.5505/ kjms.2011.097974.

4.Önmez A. Diabetes Mellitus'ta Mikrovasküler Komplikasyonların Yönetimi. Düzce Üniversitesi Sağlık Bilimleri Enstitüsü Dergisi 2017;7(2):117-119.

5.UK Prospective Diabetes Study (UKPDS) VIII. Study design, progress and performance. UK Prospective Study Group. Diabetologia 1991;34(4): 877-90.

6.Levene S, Richard D. Management of Type 2 Diabetes Mellitus: A Practical Guide. Health Sciences: London: Elsevier; 2011

7.Özdin M. Tip II Diabetes Mellituslu Hastalarda Retinopati ile HbA1c Arasındaki Ilişki. Balıkesir Medikal Journal 2020;4(2):4145.

8.Satman I. Diabetes Mellitus: Introduction, Secondary Complications. Turkiye Klinikleri J Gen Surg-Special Topics 2010;3(1):15.

9.Ergin E, Akın S, Kazan S, Erdem ME, Tekçe M, Aliustaoğlu M. Diyabetik Hastalarda Lipit Profili: Farkındalık ve Tedavideki Başarı Oranlarımız. J Kartal TR 2013;24(3):157-163. DOI:10.5505/jkartaltr.2013.82712

10.Günay GK, Bayrak TA, Özdin M. The Relationship of Lipo (a) and Paraoxonase with Diabetes Mellitus. GETATDER 2019;1(2):58.

11.Patel BN, Mackness MI, Harty DW, Arrol S, Boot Handford RP, Durrington PN. Serum esterase activities and hyperlipidemia in the streptozotocin diabetic rats. Biochemica et BiophysicaActa 1990;1035:113-116.

12.Gürsu MF, Özdin M. Lipoprotein (A) düzeyleri ile paraoksonaz (PON 1) aktivitelerinin kopmlikasyonlu ve komplikasyonsuz tip 2 diyabetik (NIDDM) hastalarda araştrılması. Fırat Tıp Dergisi. 2002;7( 2):720-726.

13.Demirez E. Tip II Diabetik Hastalarda Paraoksonaz (PON 55 ve PON 192) Gen Polimorfizmlerinin Serum PON Aktivitesi ile Etkileşimlerinin Ağız Dokusu Harabiyeti ile Olan İlişkisinin Araştrılması. Doktora Tezi. İstanbul-2006.

14.Çiftçi iN, Yur F, Çiftçi-Yeğin S. Deneysel Diyabet Oluşturulan ve Likopen Uygulanan Ratların Karaciğer Dokusunda Paraoksonaz Aktivitesinin İncelenmesi. Cumhuriyet Üniv. Sağ. Bil. Enst. Derg. 2017;1(1):01-08.

15.Özgün GS, Özgün E, Eskiocak S, Gökmen SS, Süt N, Akıncı M. Diyabetik Sıçanlarda Taurinin Paraoksonaz, Arilesteraz ve Laktonaz Aktivitelerine Etkileri. Türk Klinik Biyokimya Derg 2016;14(3):157-165.

16.Morgül G. Tip 2 Diyabetes Mellitus Hastalarında Serum Lipoprotein Düzeyleri. Uzmanlık Tezi. Adana-2008.

17.Mergen H, Mergen BE, Tavlı T, Öngel K, Tavlı V. Lipoprotein metabolizması hastalıkları ve tedavisine yaklaşım. Türk Aile Hekimliği Dergisi 2010;14(1):38-45. DOI:10.2399/tahd.10.038. 